\author{
B.H. Zhanbusinova ${ }^{1}$, G.Sh. Iskakova ${ }^{1}$, K.S. Shaukenova ${ }^{1}$, \\ B.K. Shayakhmetova ${ }^{1}$, A.K. Mukasheva ${ }^{2}$ \\ ${ }^{1}$ Ye.A. Buketov Karaganda State University, Kazakhstan; \\ ${ }^{2}$ A.Bokeikhanov school-lyceum, Shahtinsk, Karaganda region, Kazakhstan \\ (E-mail: bagdat.60@mail.ru)
}

\title{
Virtual University modules
}

\begin{abstract}
In the article the questions of filling the modules of the virtual university with teaching methods are considered. The main educational tools used in the content, as well as the types computer training programs. The work with such programs is aimed at mental actions of the student, formation and consolidation of professional skills. In the conditions of modern technologies, creative approach of teaching in professional activity is necessary. The authors show how the functions of teachers, in comparison with the traditional training system, are diversified.
\end{abstract}

Keywords: supertyutor, proftyutor, training, certification, module, unit, integration, telecommunications, infrastructure, configuration, portal, environment.

In conditions of impetuous development of modern world topical meaning have application and introduction of new information and pedagogic technologies to the education process. One of sucg forms of education is virtual education. The definition «virtual education» fully considered in works of A.V. Hutorskiy. The virtual education is a creation of virtual space where take place the process and interaction of subjects and objects of education, specific of which these objects and subjects define. The modern distant technologies allow expanding opportunities of full-time and part-time education. With using of such form of education there is an opportunity of increase mutual availability of removed students, teachers, specialists, and also information massives and virtual education objects what is important and specific.

Let's consider the issues of filling by Virtual University program modules with teaching tools. Here are the main teaching tools used in the content and also the types of computer training programs:

Work module tutorial (unit). Units are designed on each module, the average during one academic period. Each student receives 25-27 unit and methodical recommendations on work with working modular textbook.

All units have the same structure, which allows to student to orient quickly in a new academic material passing to the next module. Working modular textbook includes the course program, the didactic course plan, the list of basic and additional literature, scientific or thematic review of training material, a glossary, tasks for independent work, skills training, information to the test tasks.

The feature of the unit is the review nature of the presentation, which allows you to navigate in the basic concepts and issues, to get the basic tendencies of science development.

Training didactic or methodical tools logically complement each other and enhance didactic functions of the discipline. General view of the virtual university materials must be more than 2000 items of educational products. Among them - the simulated movies, music videos, video lectures (review and modular), satellite TV lectures, author's lecture courses, slide lectures. The best doctors and professors from different cities, different countries, professional directors should be invited to the reading and writing lectures. The Fund must be replenished regularly. All these training products are in the same and digital records and promotr to increase the visibility of the educational material content of the module or a specific part of it.

Computer training programs. The university (virtual) should have more than 300 computer-based training programs for all academic disciplines. Work with such programs aimed at enhancing the student's mental activities, the formation and consolidation of professional skills. Types of computer training programs [1]:

- Supertutor (ST) - contains all the necessary information on the topics of the course, glossary, training, testing;

- Proftutor (PT) - trains to work with professional small programs by methodological manuals;

- I-tutor (IT, imitation) - simulates a work with lengthy professional computer programs;

- G-tutor (RT, research) is a research program for the development of research skills on a specific issue;

- COMPLAY (computer game) is a game or role-playing program, immersion into the business atmosphere and performance in some role; 
- Reward is a Digital linguistic program for non-linguists;

Using of computer-based training programs is based on clear algorithms, necessarily involving feedback. Analyzing the training program A.T. Edrisov and M.A. Antonov classify them as follows [1]:

- a computer textbook is a program-methodical complex that combines the properties of usual textbooks, reference books, book of problems and laboratory practical;

- object-oriented environment (microcosms, simulation programs, training packages) is a training program package that allows you to operate with objects of a certain class, guiding by the methodological guidelines or produces research; such simulation programs give the opportunity to «stay» the head of the company, a bank, offices;

- laboratory practice serving to conduct surveillance over objects, the study of various aspects of the use of these objects in practice;

- a simulator is used for processing and securing the technical skills of problem solving;

- control programs are designed to certify the quality of knowledge;

- reference data base for educational purposes, for the storage and presentation of a variety of information; they are characterized by a hierarchical organization of the material and a quick search of information on different grounds or by the context.

Training programs represent one of the types of independent work of students on the stage when a certain knowledge is already formed.

Collective training is a classroom group session aimed to updating and processing of professional skills and allows students unleash his creativity in an interactive way. These classes are organized and conducted in accordance with the designed scenarios. Development of the script is approved by the Scientific and Methodological Council and recommended for publication and implementation in the learning process.

Guidelines for conducting collective training include the goals and objectives of the lesson, handouts, guidelines for organizing and conducting. Depending on the specifics of a particular discipline and type of lesson various types of collective training are used.

Student Appraisal System. Continuous control and assessment of assimilation quality of each module in accordance with standard criteria is also the original difference of this technology. Certification system is divided into a learning module, current and complete. Student is allowed to the current appraisal of the subject matter only after included in complex of norms stages and learning outcomes (homework, tests on modules, coursework, etc.) will be offset. Control over the passage of every student at all educational procedures is carried out by a special computer program. The student is admitted to the final certification after full current certification of all subjects in the curriculum is held. At the end of each module unit test is carried out.

Academic mobility of students is carried out through a variety of links between domestic and foreign universities and educational centers. Under the contract, even students can present their thesis and receive personal certificates and diplomas not only in the fixed educational structures, but also in other universities.

The high technology of the educational process dictates strict compliance with all of its elements, each of which is well matched with the whole chain of educational process. In the context of continuous improvement of learning technologies special measures for accelerating the teachers to adapt to the specifics of virtual learning are required. Functions of teachers in comparison with the traditional system of education is diversified in terms of modern technology a creative approach to teaching professional activity is required [2].

Summarizing the above, we note the characteristic features of virtual education.

Flexibility: students, listener receiving virtual education mostly do not attend regular classes and study at a convenient time and in a convenient location [3].

Modularity: principle is laid in the basis of virtual education programs modular: every single course creates a holistic view about a single subject area, which allows to form from the set of independent modules a curriculum that meets the needs of the individual or group.

Parallelism: training is carried out simultaneously with the professional activities (or learning in a different direction), i. e. on the job or other activity.

Large audience: the simultaneous appeal to many sources of training information, large number of students, listeners, communication with the help of telecommunication relation of students between themselves and trainees.

Effectiveness: the effective use of educational spaces and facilities, concentrated and unified view of information, the use of computer simulation and development should lead to a reduction in training costs.

Workability: the use of new advances in information technologies that assist human entry into the global information space. 
Social equality: equal access to education regardless of their place of residence, health status, social status.

Internationalization: opportunities to get education in educational institutions of foreign countries without leaving the country, and to provide educational services for foreign citizens and compatriots living abroad.

The new role of the teacher: virtual education expands and updates the role of the teacher, makes him a mentor and consultant, who must coordinate the learning process, to continually improve the courses he teaches, enhance creativity and skills in line with the innovations and innovation. Positive impact on student (listener): increasing of creative and intellectual potential of the person, who receives virtual education, at the expense of self , the pursuit of knowledge, the use of modern information and telecommunication technologies, the ability to make their own responsible decisions.

Quality: the quality of virtual education is not inferior to other forms of education because preparation for teaching resources attract the best faculty and use of the most modern teaching materials; it provided the use of a dedicated quality control of virtual education for its compliance with educational standards. The main tasks of virtual education:

- Formation of legal, organizational, educational and methodical, information and telecommunication, personnel, economic and financial security, the implementation and the development as virtual education as distance learning for individual courses or course units;

- Organization and development of virtual education in any area of training specialists; humanitarian, economic, legal, natural, military, agricultural etc;

- The introduction of virtual learning technologies at all levels (the higher, postgraduate)as well as training for individual courses or course units;

- Provide training and psychological support with the help of virtual learning socially disadvantaged groups, unemployed persons, persons with disabilities, prisoners, conscripts etc;

- Providing vocational guidance and self-determination for the future specialists;

- The use of virtual learning technologies for retraining and advanced training people in the field of business, state and municipal management, customs and tax services, financial and banking system, academics etc;

- Creation of the state electronic library of virtual courses (normative disciplines);

- Integration of virtual education system into the world of modern education.

- The organizational structure brings together all the components of the virtual education and based on the following components:

- Organizational and management;

- Normative-legal;

- Educational and methodical;

- Information and telecommunications;

- Economic and financial.

It provides:

-preparation of legal documents of the virtual education projects;

- coordinate of development and implementation of virtual learning technology and curricula;

- development of virtual courses with international standards of virtual education;

- coordination of virtual education centers on the interaction with regional and regional telecommunications centers;

- the development and implementation of the most effective information and educational software;

- creation of a distributed information structure of virtual education as well as administration system and control of knowledge;

- the development of programs, providing training and retraining personnel for the virtual education;

- the development of a system of information and analytical support for virtual education, including market research and promotional activities.

Regional centers of virtual education. They are created on the basis of the higher educational institutions, which are the regional centers of the telecommunications network of science and education. Provide the ability to use the telecommunications network. Take part in:

- In the improvement and development of telecommunications infrastructure for the implementation of virtual education;

- In the preparation of legal documents of virtual education projects;

- In the development and implementation of virtual learning technology and curricula;

- In the development and implementation of the most effective information and educational software; 
- In the creation of distributed information structure of the virtual education;

- In the preparation of virtual education staff;

- In the establishment of the state library of virtual courses.

Regional centers may be basic centers in areas of vocational training.

Basic centers in areas of vocational training. They are created on the basis of higher educational institutions with outstanding educational-methodical and scientific developments in one or more areas of professional training; have a significant contribution to the development and implementation of the virtual learning technologies and accordingly prepared cadre. They provide:

- The development of virtual courses on specific areas of the Coordination Council of vocational training;

- The introduction of virtual education in the relevant areas of vocational training.

- Participants:

- In the preparation of legal documents virtual education projects;

- In the development in areas of training specialists teaching methods;

- In making recommendations on the introduction of information technologies and virtual courses in the various forms of education;

- The establishment of administration system and control of knowledge;

- The establishment of the state library of virtual courses.

Local centers of virtual learning. They are created on the basis of higher educational institutions with access to telecommunications networks, modern computer facilities and trained personnel structure. Stages of creation and development of virtual education. Creation of the basic foundations of virtual education system may be implemented in the following stages.

First step:

- Establishment of the organizational structure of virtual education;

- The development of regulatory frameworks and virtual education standards;

- Monitoring study of the implementation conditions of virtual education and optimization of the process;

- Creation of the material - technical base of the regional local centers of virtual learning;

- Creation of a primary fund of virtual courses and ensure their experimental implementation;

- Development of Financing bases of virtual learning;

- The implementation of pilot implementation projects of virtual education. Second step:

- Full-scale deployment and implementation of virtual education as a form of learning;

- The introduction of multi-channel system of financing businesses and individuals of virtual education;

- The introduction of a licensing system, certification and accreditation of virtual education institutions.

Consider approaches to the development of information and telecommunication resources and the results of their implementation ensured the successful task solution of creating the foundations of a common information space. Telecommunications basis providing interaction and remote access to information resources can be a segment of the scientific and educational RunNet computer network having a gateway to all the commercial networks and managed with the use of specially developed integrated network management system. This system may include five interrelated subsystems to solve individual problems, which include:

- Configuration Management;

- Security management;

- Management failures;

- Accounting of the resources use;

- Performance Management.

The backbone core is a database complex containing complete information about all aspects of the network functioning. It allows the administrator to obtain the necessary information at any time.

Within this network segment you can create information portal and web portal providing a total access to the main information resources.

At the same time one of the most representative scientific and educational information resources available online can be e-library (Automated Library Information System - ALIS), the Bible - graphic description of the library collection?s documents and their full-text electronic copies can be accumulated in its databases.

The library is considered as one of the main elements of the virtual learning system providing it quick access from remote locations to the necessary teaching materials. Overall ALIS provides with managing formation of the library collection through the creation and use of images of the search documents: an analysis of the composition of the fund; determining the presence of teaching materials necessary for the successful conduct of 
training activities; implementation of selection of documents in accordance with the permanent and one-time requests of the users in the modes of selective distribution of information and retrospective search; preparation of various lists and literature indexes, the necessary forms of report documents: easy and convenient access to information for different categories of users including from remote locations; interaction with other similar systems by the Internet; the creation on its base of corporate ALIS city.

This system bases on the complex of automated workplaces (AWP) and electronic catalogs containing bibliographic, factual and full-text databases formed on the basis of new acquisitions and the existing stock; AWP for acquisition fund; AWP of the bibliographer; AWP of the reader; AWP of the librarian; AWP for the interlibrary loan; System Administrator workstation.

Created within IntraNet ALIS bases on the use of opportunities database management system (DBMS) Oracle8. Documents introduced in the system immediately after the entry is made available to users through a Web-based workstations with a data-processing network and from remote workstations with access to telecommunications networks.

The choice of methods and tools of information systems development is carried out with the following requirements to them:

- Multiplatform support;

- Regardless of the manufacturer;

- Commonality;

- Ability to create a reliable and quality software;

- The ability to support software developed during the entire lifetime;

- Ability to design using modern methods and approaches;

- The possibility of development and a simple modification of the developed system; A simple and effective support for Web-technologies.

Creating information systems focuses on the complex means of interaction with the end user who performances a «smart interface» role on modern level and enables interactive solution of information problems on a computer. Note that for this purpose capabilities of the Web environment are widely used; this capabilities ensure the provision of a user interface for working with one or more databases. Thus, it can be seen that the known three-tier client-server architecture of the database is displayed naturally on the Web environment, where the Web - browser plays a role of a «thin» client, a Web-server - the role of the application server. In such manner, forming of virtual education space with all its flowing peculiarities, modules and means on the base of the modern information achievements is one of the important tasks of education system of XXI century [3].

\section{References}

1 Едрисов А.T., Антонов M.А. Технология компьютерного программированного обучения // Состояние и стратегия развития дистанционного образования в условиях глобализации: материалы Междунар. науч.-практ. конф. - Караганда: КРУ, 2003. - С. 129-133.

2 Морозов В.А. Креативность преподавателя высшей школы // Высшее образование сегодня. - 2004. - № 3. - C. 64-72.

3 Методологические вопросы наполнения программных модулей виртуального университета // Университет ШОС - новые горизонты дистанционного образования: опыт, практика, перспетивы развития: материалы науч.-практ. конф. - Караганда: КЭУК, 2013. - С. 86-92. 


\author{
Б.Х. Жанбусинова, Г.Ш. Искакова, К.С. Шаукенова, \\ Б.К. Шаяхметова, А.К. Мукашева
}

\title{
Виртуалды университеттің модульдері
}

\begin{abstract}
Мақалада виртуалды университеттің модульдары мазмұны оқу-әдістемелік әдістермен толтырылу мәселелері қарастырылған. Контентте пайдаланатын негізгі оқу әдістері, сондай-ақ компьютерлік оқу бағдарламалары түрлері көрсетілген. Осындай бағдарламалар студенттің зерделі әрекетін белсендіруге, кәсіби дағдыларын бекітуге бағытталған. Қазіргі технологияларының сабақ берудің креативті тәсілі бірінші кезекте екендігі белгіленіп, авторлармен дәл осылай үйретудің, дәстүрлі жүйесімен салыстырғанда, оқытушылардың қызметін жандандырады деген қорытынды жасалған.
\end{abstract}

Kiлm сөздер: виртуалды университет, контент, кәсіби дағды, заманауи технологиялар, зерделі әрекет.

\author{
Б.Х. Жанбусинова, Г.Ш. Искакова, К.С. Шаукенова, \\ Б.К. Шаяхметова, А.К. Мукашева
}

\section{Модули виртуального университета}

В статье рассмотрены вопросы наполнения учебно-методическими средствами модулей виртуального университета. Приведены основные учебные средства, используемые в контенте, а также виды компьютерных обучающих программ. Работа с такими программами направлена на активизацию умственных действий студента, формирование и закрепление профессиональных навыков. В условиях современных технологий необходим креативный подход преподавания в профессиональной деятельности. Авторами показано, как функции преподавателей, в сравнении с традиционной системой обучения, диверсифицируются.

Ключевые слова: виртуальный университет, контент, профессиональные навыки, современные технологии, умственные способности.

\section{References}

1 Edrisov A.T., Antonov M.A. Status and Strategy of development of distance education in the context of globalization, Materials of the International scientific and practical conference, Karaganda: KazakhRussian University, 2003, p. 129-133.

2 Morozov V.A. Higher education today, 2004, 3, p. 64-72.

3 Methodological issues of filling of program modules of the university, Materials of scientific and practical conference of the University SCO - new horizons of distant education: experience, practice, development perspectives, Karaganda: Karaganda economic University, 2013, p. 86-92. 